\title{
SELECTED ECONOMIC ASPECTS OF ADOPTING A LOCAL SPATIAL DEVELOPMENT PLAN EXEMPLIFIED BY THE COMMUNE OF TOMICE IN MALOPOLSKIE PROVINCE
}

\author{
Krzysztof Gawroński, prof. PhD \\ Faculty of Environmental Engineering and Land Surveying \\ University of Agriculture in Kraków (Poland) \\ e-mail:krzysztof.gawronski@ur.krakow.pl \\ Barbara Prus, PhD \\ Faculty of Environmental Engineering and Land Surveying \\ University of Agriculture in Kraków (Poland) \\ e-mail:b.prus@ur.krakow.pl
}

\begin{abstract}
The object of this article is to analyze and asses the legal and economic consequences arising from the adoption (or change) of a local spatial development plan. The paper also presents, based on the example of the rural commune of Tomice in the Malopolska Province of Poland, how to estimate income to the commune budget from the collected planning fees. The analyses are based on planning studies, including the local spatial development plan from 2004, and the study of conditions and directions of spatial development from 2012. The council of Tomice Commune adopted the local spatial plan due to the increasing demand for residential areas. According to the plan, over 930 acres of land have been allocated for investment purposes, which is approx. $22.4 \%$ of the total area of 4,155 ha. The local plan was developed for all the six cadastral units of the commune, with one hundred percent surface coverage. The physiographic conditions and the location of Tomice Commune encourage the settlement of the urban population (from Wadowice or Krakow), which entails the need for housing investment areas. In 2012, the Tomice Commune adopted a change in the study of conditions and directions of spatial development. The proposed re-zoning of the area is in line with the policy of transitioning from an agricultural character towards the sustainable and multifunctional development of the commune. It is worth noting that the provisions of the plan of 2004 take into account the collection of a one-time fee for the sale of real estate whose value has increased as a result of the adoption of the plan. The amount of this fee for investment areas was set at the level of $30 \%$ of the increase in value, in accordance with the provisions of the Polish Act on Spatial Planning and Management. Due to the fact that the currently valid local plan has been in effect for 10 years, it can be assumed that the commune will proceed to make some changes to it. The article estimates the potentially generated income, assuming that changes in the study passed in 2012 with regards to designating land for investment purposes constitute an indication of provisions in the future local plan.
\end{abstract}

Keywords: planning fee, financial results of adoption of or change in local spatial plan.

JEL Classification: R14, Q5.

Citation: Gawroński K., Prus B., 2015, Selected Economic Aspects of Adopting a Local Spatial Development Plan Exemplified by the Commune of Tomice in Malopolskie Province, Real Estate Management and Valuation, Vol. 23, No. 4, pp. 5-15.

DOI: $10.1515 /$ remav-2015-0031 


\section{Introduction}

Planning activity, which is expressed in real life by the optimal shaping of space, is strictly conditioned by economic considerations. The currently promoted idea of sustainable development requires planning which is consistent with the needs of local communities. When planning future land use and development, it is necessary to also keep economic aspects in mind in addition to the ecological ones (DUDZIŃSKA, KOCUR-BERA 2014). BAJEROWSKI (2008) argues that any given planning activity will be effective only on the condition that economic benefits are achieved (BÜRGI, HERSPERGER, SCHNEEBERGER 2005). Economic aspects are discussed together with a forecast of the financial consequences of passing a local spatial plan for a commune. Recent years have shown a growing demand for land for investment projects. The transformation of more and more agricultural land for non-agricultural and non-forest purposes (FOGEL 2010; PRUS 2012) increases the phenomenon of the suburbanization of rural areas (BAŃSKI, WESOŁOWSKA 2013; MROZIK, WIŚNIEWSKA 2013; MROZIK, BOSSY, ZARĘBA 2012). Unfortunately, the transformation of agricultural land into an investment area does not always coincide with demographic forecasts (SPRINGER 2013, FOGEL 2010), but is instead a political tool in the hands of local authorities. This is strongly linked to the aspect of property ownership and desire to achieve the highest possible economic benefits associated with it. The right of ownership is the most complete form of object use, amongst all the possible rights; this form also provides the most significant benefits. Ownership is not only a legal concept but also an economic category (KWAŚNIAK 2009) according to which property is any form of possession of parts of nature which have a financial value. The challenges related to land management and, indirectly, also planning are reflected in the Polish Constitution, the provisions of which state that the Republic of Poland shall protect ownership rights and expropriation may be allowed solely for public purposes (KONSTYTUCJA RP). At the same time, one can say that the protection of ownership rights is one of the principles of the Polish economic system (SKRZYDEO 2002), as well as other European countries (HERNIK, GAWROŃSKI, DiXON-GOUGH 2013).

The Polish Act on Spatial Planning and Management (UstaWA 2003) is the fundamental act of law in Poland in this respect. In the provisions related to the legal results of adopting (changing) local spatial development plans, this Act introduces regulations focussed on the relationship between the execution of property rights and the content of the local spatial plan (HAUSER et al. 1995; BIEDA et al. 2012). In the context of spatial planning, everyone has the right to demand protection of their own interests through legal channels.

The aim of this study is to characterize selected problems with regards to property rights in the context of spatial planning, in particular the legal and economic effects of adopting (changing) local spatial development plans. The practical part of the work presents this issue based on the example of the Tomice Commune, located in the Malopolskie Province of Poland. The commune is a good research object for the needs of this study as it is located in the immediate vicinity of the town of Wadowice. Tomice is a residential area for those working in Wadowice, as well as for the nearby city of Krakow. The study uses the method of descriptive and comparative analysis, as well as simple statistical methods.

\section{Economic results of adopting (changing) a local spatial plan - theoretical point of view}

Local spatial planning is an important matter in the hands of local commune authorities (ŚwIETLIK 2003). Proposals related to commune development included in the study of conditions and directions of spatial development and next, their formal implementation in the local spatial plan, are all indicators of local spatial order (CYMERMAN 2011). Apart from shaping the image of local spatial management, which also includes the cultural landscape, the decisions of local authorities bring economic effects. Subsequent exclusions of land from agricultural production not only change the appearance of areas but also entail increases in taxes, which are direct sources of income for the commune. When deciding to draw up planning documents, the commune spends funds from the commune budget. Some of them may be compensated by income generated by planning fees, the level of which will depend on the size of the areas whose land use designations were changed, as well as being determined by the commune council, who establishes various rates for various designation changes. The financial analysis should also account for any potential "losses" in the commune budget resulting from designation changes that reduce the market value of properties. The Act on Spatial 
Planning and Management refers to two basic cases in this respect (USTAWA 2003) ${ }^{1}$. The first case is a situation when, in connection with the adoption of the local plan or a zoning change, the use of a property or part thereof, in the previous manner consistent with the current or intended use, has become impossible or significantly limited. In such a case, the owner or usufructuary may require the commune to grant compensation for the actual harm suffered, or purchase the real estate or part thereof (USTAWA 2003, KWAŚNIAK 2009). The principle of compensation for losses incurred by the property owner or usufructuary in connection with the adoption or amendment of a local spatial plan is not a new solution in Polish legislation (GAWROŃSKI 2008).

The second case occurs when the adoption or change in the local spatial plan increases the value of property, and the owner chooses to sell it. Then, the local administration authorities charge a one-time fee (planning fee), the level of which is determined as a percentage amount of the increase in the property value. Such a situation takes place when both of the following conditions are met:

- a change of property value happens as a result of the adoption or amendment of the local spatial plan,

- property is sold within 5 years from the moment the new plan was passed (SzWAJDLER, BĄKOWSKI 2004).

The fee depends on the increase in property value, yet cannot exceed $30 \%$ of the increase. The amount can be established by the commune council when passing the local spatial plan. It is commonly referred to as the planning fee and constitutes an additional form of income. The early 20th century was a time when the following thesis was developed: the price of building land is equal to the price of agricultural land increased by capitalized location-related advantages. The planning fee may, therefore, be established as a result of the adoption of or change in legally binding planning studies referring to the given property. This results in a change in its utilization properties, which in turn causes an increase or decrease of its economic value (CYMERMAN, GRABOWSKI 1999).

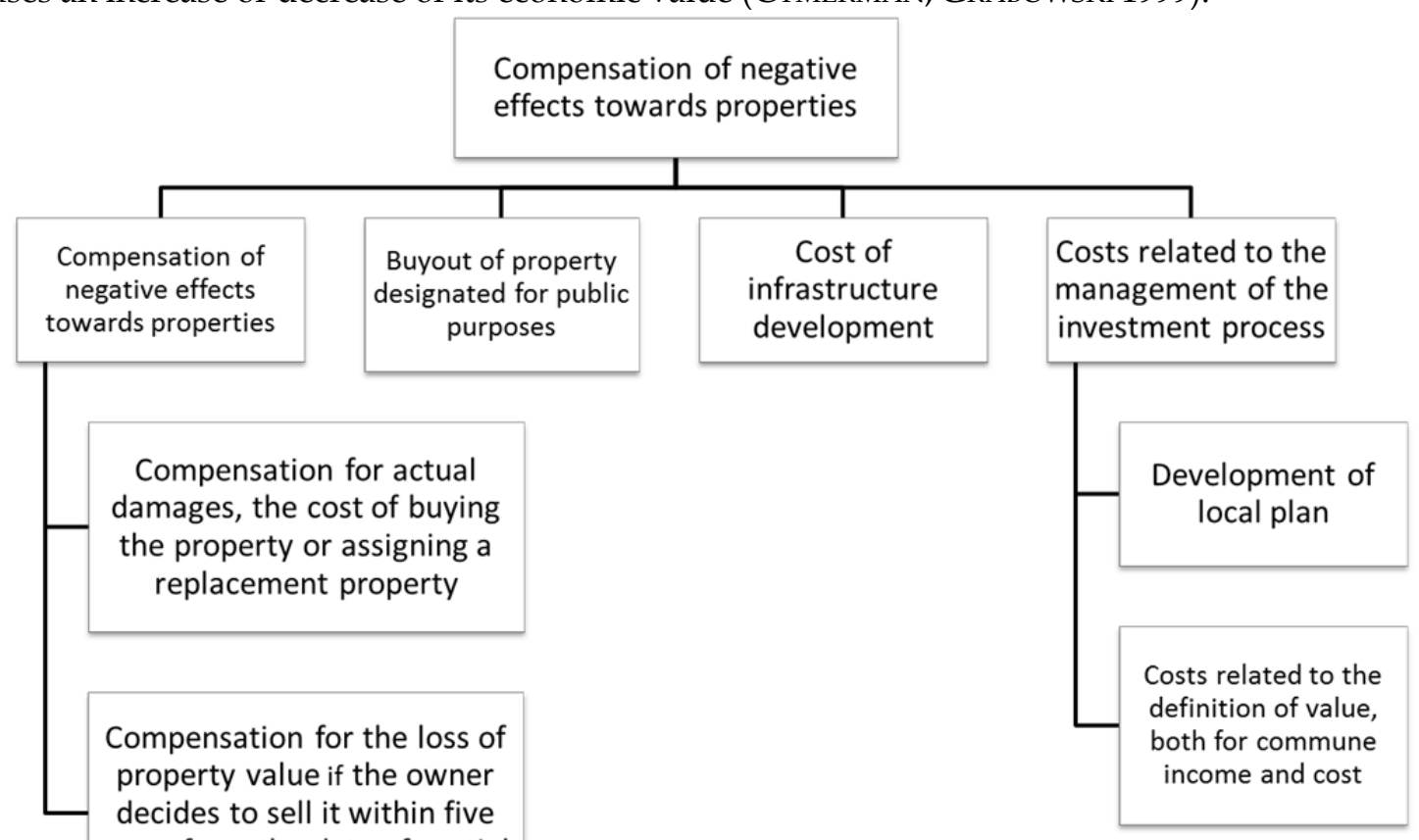
years from the date of spatial plan adoption

Fig. 1. Financial expenditures related to the implementation and adoption of local spatial plans. Source: own work based on CYMERMAN, BAJEROWSKI, KRYSZK (2008).

\footnotetext{
1 Act of 27 March 2003 on Spatial Planning and Management (Journal of Laws, No. 80, item 717 as amended). Planning fee is not collected in the case of an unpaid transfer of ownership rights to a farm by a farmer to the successor. This is based on the Act of 20 December 1990 on the Farmer Insurance System or regulations on special conditions for granting financial aid within the framework of early retirement for farmers.
} 
The draft of a local spatial plan is supported by a forecast regarding the financial impact of the adoption of the plan. The forecast is not legally binding; it plays the role of an economic analysis (ŚWIETLIK 2004, KWAŚNIAK 2009, NIEWIADOMSKI 2003). Detailed information related to the forecast is defined in the Regulation of the Ministry of Infrastructure of 26 August 2003 on the required scope of the draft of the local spatial plan (Dz. U. No 164, item. 1587 issued in 2003). This document should include, in particular, the forecasted impact of the local spatial plan on the following (ROZPORZĄDZENIE 2003):

1. commune revenue and expenses, including revenue from property tax and other income related to the real estate market, fees and compensation,

2. expenses related to investment in technical infrastructure, which is solely the responsibility of the commune,

3. conclusions and recommendations for the adoption of the proposed solutions to the local spatial plan, resulting from the consideration of their legal effects.

It is also possible to draw up several drafts of the local plan, and then determine, with help of financial effect prognosis, which of the projects achieves the highest financial benefits (BAJEROWSKI 2008, CZEKIEL-ŚWITALSKA 2002). Financial implications (expenses - Figure 1 and income - Figure 2) are associated with the adoption of a local spatial plan and appear already at the preparatory stage: with work on the project, land surveying work, or tasks associated with equipping the land with technical utilities infrastructure.

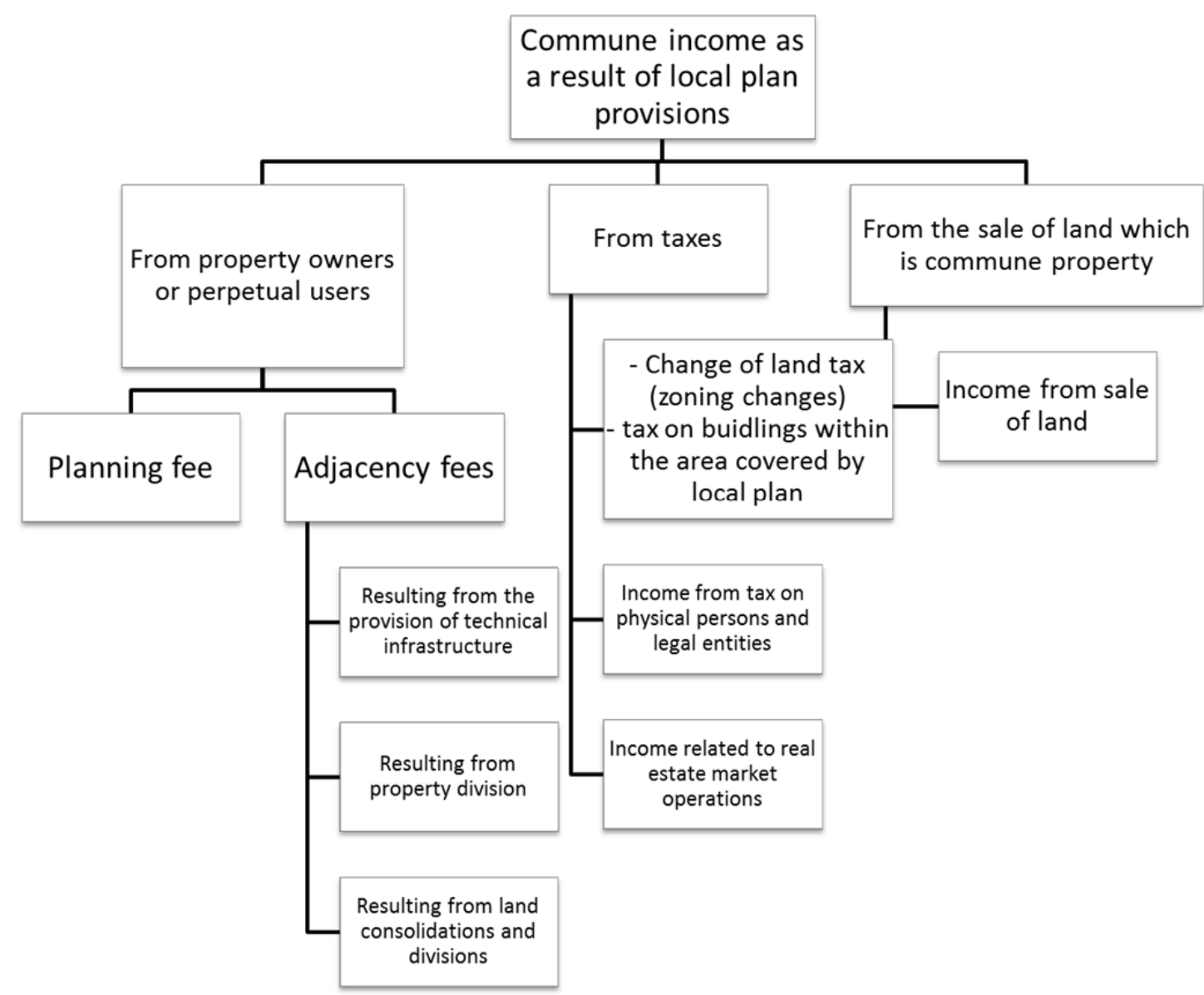

Fig. 2. Commune income resulting from the adoption of a local spatial plan. Source: Own work based on the Regulation of the Ministry of Infrastructure of 26 August 2003 on the required scope of the draft of the local spatial plan (Dz. U. No 164, item. 1587 issued in 2003).

The preparatory stage also includes administrative and legal actions, which entail some costs burdening the commune budget, such as the creation of the local spatial plan. This is the stage when the undertaken decisions may affect changes in property value. The implementation stage is the last stage when the financial effects of the adoption of the spatial plan can appear. Planned technical 
infrastructure may have a positive or negative influence on the value of property. This depends on the final designation of the given plot(s) of land and adjoining areas. For example, in the case of a planned transit road, the value of properties for residential purposes will go down, yet the value of those designated for industrial or service purposes will increase (CYMERMAN, BAJEROWSKI, KRYSZK 2008). Therefore, the solutions introduced in the Act on Spatial Planning and Management (2003) and related to the legal consequences of adopting (changing) spatial plans, have a significant impact on budget management in the commune, both in the context of revenues and income.

\section{Research results}

\subsection{Decisions of the 2004 Local Spatial Plan with regards to the location of investment areas}

The local spatial plan for Tomice was developed and adopted in 2004, in accordance with commune spatial policy expressed in the study of conditions and directions of spatial development. The adopted plan overturned the previously binding fragmentary plans, covering only selected areas of the Tomice Commune, for example the plan of 1998 regarding the designation of land for business activity in Tomice.

The local spatial plan for Tomice adopted in 2004 defines 21 different zoning categories marked with 33 symbols. The category of investment areas includes residential and service development zones (for boarding houses, recreational facilities, summer houses, tourism-related facilities) marked with the following symbols: MN, MU1, MU1X, MU2, MP, and agricultural and residential zones (for farm buildings, local workshops and small manufacturing facilities), marked as: MRX, MR, RM, RMX. The plan also determines zones for public services: UC1, UC1X, UC2, UK, UP, US.

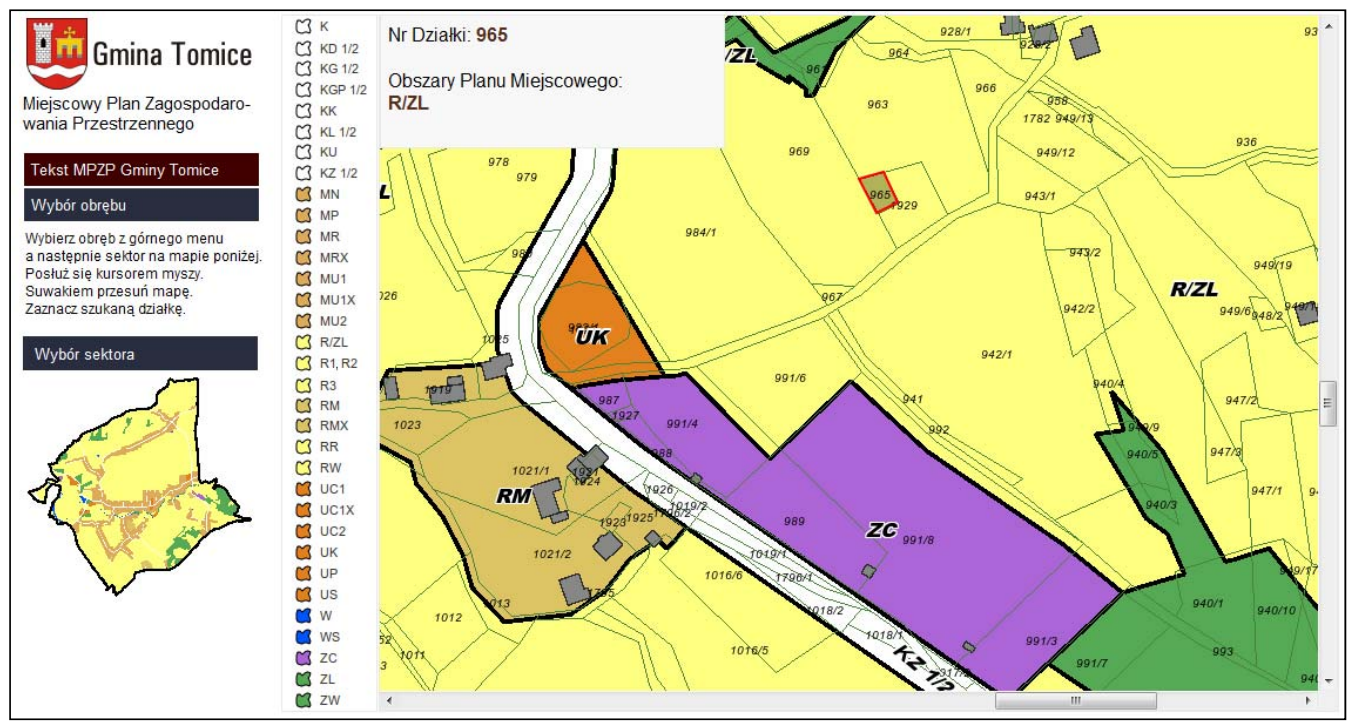

Fig. 3. Excerpt from the Local Spatial Plan of 2004 for Tomice. Source: http://www.tomice.pl.

Based on the local spatial plan, the most common zones among investment areas in Tomice include residential and service zones, and agricultural development zones (Table 1). Altogether, these cover over $77 \%$ of the total investment area.

Investment areas in the local spatial development plan for Tomice from 2004

Table 1

\begin{tabular}{cccccc}
\hline \multirow{2}{*}{$\begin{array}{c}\text { Investment } \\
\text { zone symbol }\end{array}$} & \multicolumn{2}{c}{$\begin{array}{c}\text { Size of investment } \\
\text { areas }\end{array}$} & $\begin{array}{c}\text { The } \\
\text { number } \\
\text { of zones }\end{array}$ & $\begin{array}{c}\text { Min. area } \\
\text { of zone }\end{array}$ & $\begin{array}{c}\text { Max. area of } \\
\text { zone }\end{array}$ \\
\cline { 2 - 6 } & ha & $\%$ & - & ha & ha \\
\hline RM & 47.22 & 5.08 & 16 & 0.13 & 9.32 \\
\hline UC1X & 14.32 & 1.54 & 4 & 0.35 & 10.62 \\
\hline MN & 13.11 & 1.41 & 5 & 1.33 & 5.85 \\
\hline MP & 5.21 & 0.56 & 5 & 0.49 & 1.82 \\
\hline US & 3.76 & 0.40 & 4 & 0.66 & 1.37 \\
\hline
\end{tabular}




\begin{tabular}{cccccc}
\hline RMX & 5.81 & 0.62 & 6 & 0.25 & 1.58 \\
\hline MU1X & 59.76 & 6.42 & 14 & 1.35 & 8.85 \\
\hline UK & 1.93 & 0.21 & 6 & 0.09 & 1.15 \\
\hline MRX & 12.79 & 1.37 & 7 & 0.10 & 8.21 \\
\hline MR & 298.94 & 32.13 & 104 & 0.03 & 11.63 \\
\hline UC2 & 5.31 & 0.57 & 1 & 5.31 & 5.31 \\
\hline MU2 & 14.10 & 1.52 & 7 & 0.17 & 4.39 \\
\hline MU1 & 422.56 & 45.42 & 114 & 0.04 & 29.76 \\
\hline UC1 & 10.80 & 1.16 & 12 & 0.27 & 2.11 \\
\hline UP & 14.68 & 1.58 & 12 & 0.09 & 7.76 \\
\hline RAZEM & 930.30 & $100 \%$ & 317 & - & - \\
\hline
\end{tabular}

Source: own work based on own research.

The highest percentages of investment areas are located in the village of Tomice (Commune Council seat): $29.0 \%$. A large proportion of investment land (Table 2) is also located in Radocza (25.4\%) and Witanowice (16.8\%). Almost 55\% of Tomice's investment areas include those for residential development and services. The highest percentage of these in relation to investment land is found in Tomice (85\%) and Radocza (67\%).

Table 2

Size of investment areas in the local spatial development plan for Tomice according to individual villages

\begin{tabular}{|c|c|c|c|c|c|c|}
\hline \multirow{2}{*}{ Village } & \multirow{2}{*}{$\begin{array}{c}\text { Total area } \\
\text { [ha] }\end{array}$} & \multicolumn{3}{|c|}{ Size of investment areas } & \multicolumn{2}{|c|}{$\begin{array}{c}\text { Size of } \\
\text { agricultural } \\
\text { production areas }\end{array}$} \\
\hline & & ha & $\begin{array}{c}\% \text { of village } \\
\text { area }\end{array}$ & $\begin{array}{c}\% \% \\
\text { total } \\
\text { area }\end{array}$ & ha & $\begin{array}{c}\% \text { total } \\
\text { area }\end{array}$ \\
\hline Tomice & 766.9 & 269.5 & 29.0 & 6.5 & 450.2 & 10.8 \\
\hline Zygodowice & 419.8 & 74.6 & 8.0 & 1.8 & 333.8 & 8.0 \\
\hline Woźniki & 571.2 & 115.6 & 12.4 & 2.8 & 396.6 & 9.5 \\
\hline Witanowice & 946.8 & 156.5 & 16.8 & 3.8 & 676.1 & 16.3 \\
\hline Radocza & 957.8 & 235.8 & 25.4 & 5.7 & 607.5 & 14.6 \\
\hline Lgota & 492.4 & 78.2 & 8.4 & 1.9 & 283.9 & 6.8 \\
\hline TOTAL & 4154.9 & 930.3 & $100 \%$ & 22.4 & 2748.1 & 66.1 \\
\hline
\end{tabular}

Source: own work based on own research.

The villages of Zygodowice, Woźniki, Witanowice and Lgota appear to have a primarily agricultural function - they are dominated by areas of agricultural production. In Lgota, the percentage of agricultural plots is almost $92 \%$ of all investment areas. In Witanowice, this is slightly lower: $72 \%$ of investment areas are linked to the agricultural function. Similar is the case of Zygodowice, where the percentage is $62 \%$. The village of Woźniki can be considered as the border between an agricultural settlement and settlement with multidirectional development potential. Agricultural areas occupy slightly more than 50\% of all investment areas.

3.2. Comparative analysis of the local spatial development plan of 2004 and the study of conditions and directions of spatial development adopted in 2012 with estimated income from planning fees

Directions of spatial development outlined in the study of conditions and directions of spatial development for Tomice indicate an increase in investment areas. This increase may result from demographic reasons; on 31 December 2013, the commune of Tomice had fewer than 7.8 thousand inhabitants.

Table 3

\begin{tabular}{ccccccccccc}
\hline & 2004 & 2005 & $\mathbf{2 0 0 6}$ & $\mathbf{2 0 0 7}$ & $\mathbf{2 0 0 8}$ & $\mathbf{2 0 0 9}$ & $\mathbf{2 0 1 0}$ & $\mathbf{2 0 1 1}$ & $\mathbf{2 0 1 2}$ & $\mathbf{2 0 1 3}$ \\
\hline $\begin{array}{c}\text { Population as of } \\
\text { 31 December }\end{array}$ & 7168 & 7227 & 7273 & 7345 & 7426 & 7464 & 7640 & 7700 & 7742 & 7798 \\
\hline
\end{tabular}




\begin{tabular}{ccccccccccc}
\hline Migration ratio & 56 & 31 & 12 & 45 & 44 & 12 & 12 & 8 & 19 & 33 \\
\hline $\begin{array}{c}\text { Migration ratio } \\
\text { per 1000 } \\
\text { inhabitants }\end{array}$ & 7.9 & 4.3 & 1.7 & 6.2 & 6.0 & 1.6 & 1.6 & 1.0 & 2.5 & 4.2 \\
\hline Birth rate & 10 & 28 & 34 & 27 & 37 & 26 & 46 & 52 & 26 & 30 \\
\hline $\begin{array}{c}\text { Birth rate per 1000 } \\
\text { inhabitants }\end{array}$ & 1.4 & 3.9 & 4.7 & 3.7 & 5.0 & 3.5 & 6.0 & 6.8 & 3.4 & 3.9 \\
\hline
\end{tabular}

Source: Polish Central Statistical Office /http://www.stat.gov.pl/ accessed on: 5 May 2015.

Compared to the year 2004, the number of inhabitants increased by approx. $8.8 \%$. This resulted from both a positive natural increase as well as positive migration ratio in the years 2004-2013, which ranged from 1.0 to 7.9 per 1 thousand inhabitants (Table 3).

The study provides for the development of buildings along main roads and in between existing buildings. However, what hinders future construction plans are landslide areas. These constitute a serious limitation to allocating land for residential purposes (BYDŁOSZ, HANUS 2013).

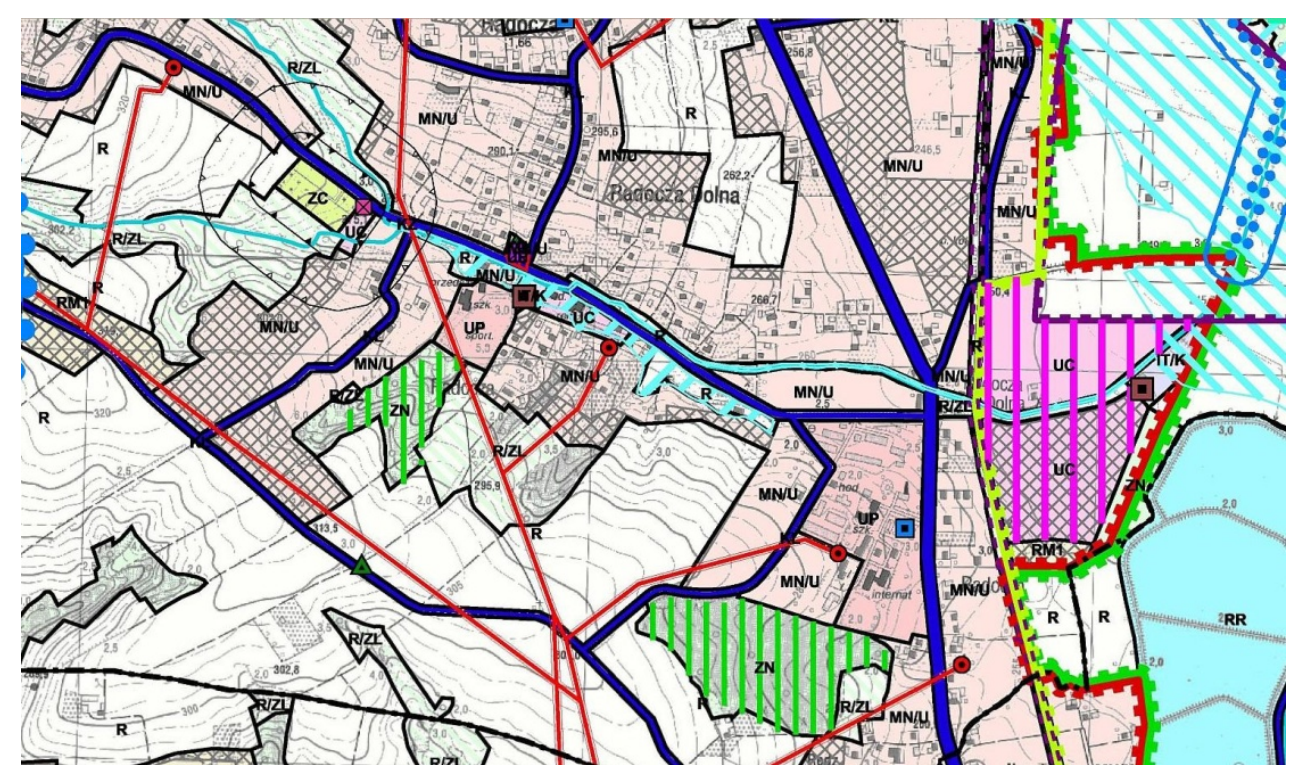

Fig. 4. Excerpt from the study of conditions and directions of spatial development of Tomice from 2012. Source: http://www.tomice.pl.

The presented estimate of income from planning fees for the researched commune includes the following steps and assumptions:

1. The comparison of investment zones designated in the spatial plan from 2004 with zones provided for future building development in the study of conditions and directions of spatial development from 2012 (Figure 5) revealed that 1,324 plots (which constitutes approx. 19\% of all plots in Tomice) fulfil the criteria for collecting a planning fee, due to an increase in property value caused by changes in land use designation in the local spatial development plan. It needs to be noted here, however, that at the moment there are no formal grounds for setting planning fees. This will be possible only after the adoption of the new local spatial development plan.

2. Nevertheless, assuming that the provisions of the study precede properly binding regulations of the local spatial development plan, it was calculated that the area of plots of land which would qualify for planning fees would amount to almost 600 ha in total in all the villages. Spatial analysis presented in Figure 5 was created by the juxtaposition of zones determined in the local plan and directions of development determined in the study of conditions and directions of spatial development (UNIWERSAŁ 2014).

3. The largest plot which was qualified as potentially subject to the planning fee is approx. 7.82 ha, whilst the smallest one has an area of merely $0.0018 \mathrm{~m}^{2}$. The average area of a plot that can be subject to the planning fee is approx. 0.45 ha, based on calculations of the areas of all selected plots. The highest number of plots which would be subject to the planning fee is located in 
Witanowice (303), next in Tomice (273), Radocza (258) and Woźniki (251). The lowest number can be found in Lgota (148) and Zygodowice (91).

4. The assumed rate of the planning fee related to the increase in plot value is $10 \%$ (lower than the rate assumed in 2004, which was 30\%). It was also assumed that the average increase in plot value is $20 \mathrm{PLN} / \mathrm{m}^{2}$. This assumption was made based on the empirical analysis of land value in the commune of Tomice (POMPKA, 2013). Another assumption was the probability of selling the property in the future years (Table 3). Based on this, Table 4 shows the estimated level of income from planning fees in the subsequent years after passing the local spatial development plan. It was assumed that $20 \%$ of plots which are subject to the planning fee will be sold in the first year after the adoption of the local plan (Table 4).

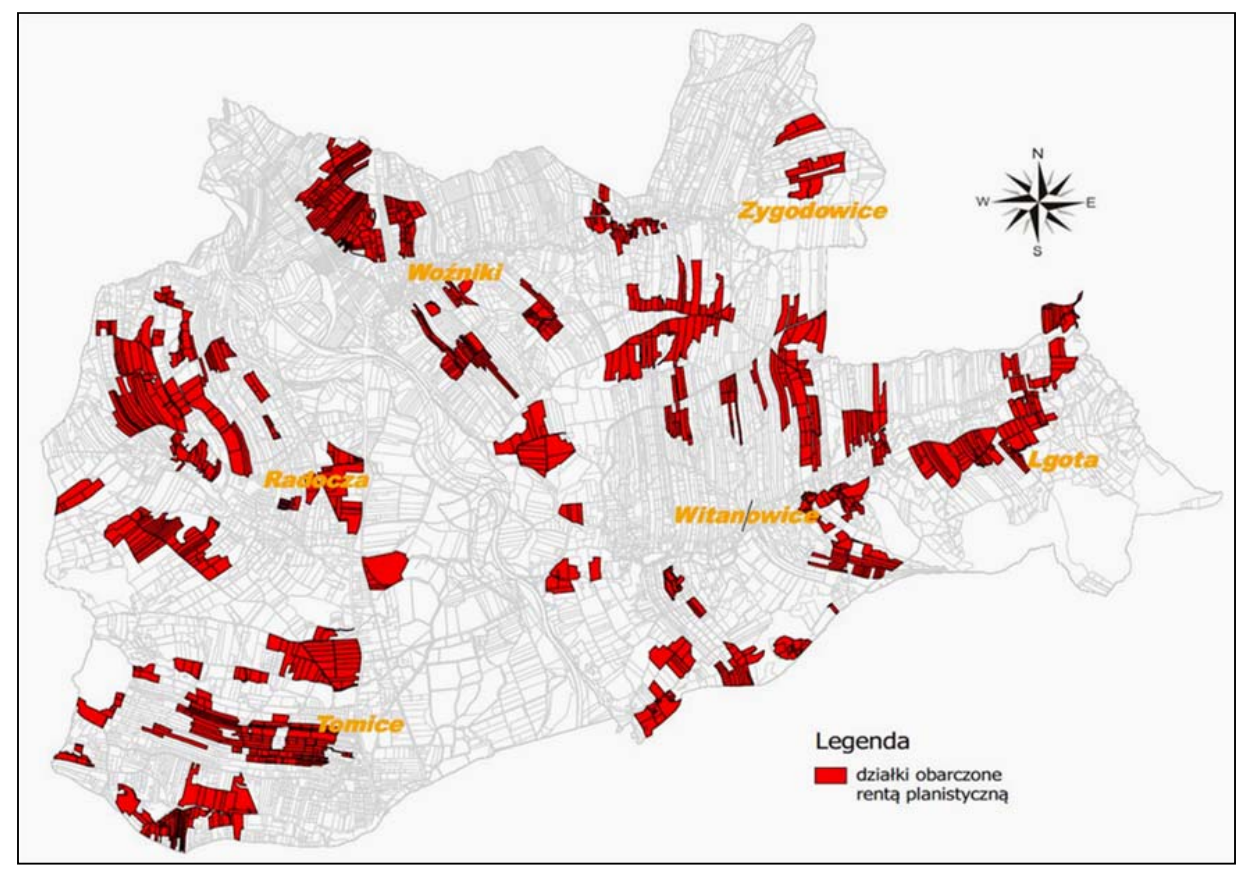

Fig. 5. Distribution of plots potentially subject to the planning fee in 2013 in the commune of Tomice. Source: UNIWERSAE (2014).

Table 4

Probability of property sales in the subsequent years after passing the local plan together with a forecast of the number of sold plots and hypothetical increase in value, as well as the amount of the planning fee

\begin{tabular}{cccccc}
\hline $\begin{array}{c}\text { Years } \\
\text { after } \\
\text { change } \\
\text { of local } \\
\text { plan }\end{array}$ & $\begin{array}{c}\text { Probability } \\
\text { of property } \\
\text { sale }\end{array}$ & $\begin{array}{c}\text { Estimated } \\
\text { number of } \\
\text { sold plots }\end{array}$ & $\begin{array}{c}\text { Assumed } \\
\text { average area of } \\
\text { plot } \mathbf{0 . 4 5} \text { ha }\end{array}$ & $\begin{array}{c}\text { Difference in } \\
\text { value with an } \\
\text { assumed } \\
\text { increase of 20 } \\
\text { PLN/m }\end{array}$ & $\begin{array}{c}\text { Projected income } \\
\text { with planning } \\
\text { fee rate at 10\% of } \\
\text { value change } \\
\text { (PLN) }\end{array}$ \\
\hline 1 & 0.20 & 265 & 119.16 & $23,832,000$ & $2,383,200$ \\
\hline 2 & 0.30 & 318 & 142.99 & $28,598,400$ & $2,859,840$ \\
\hline 3 & 0.10 & 74 & 33.36 & $6,672,960$ & 667,296 \\
\hline 4 & 0.10 & 67 & 30.03 & $6,005,664$ & 600,566 \\
\hline 5 & 0.05 & 30 & 13.51 & $2,702,549$ & 270,255 \\
\hline $6,7,8 \ldots$ & 0.25 & 143 & 64.19 & - & - \\
\hline \multicolumn{2}{r}{ Total } & 896 & - & $67,811,573$ & $6,781,157$ \\
\hline
\end{tabular}

Source: own work based on probability indexes from SŁOJEWSKI, WITKIEWICZ (2005).

5. In the subsequent years, the initial number of plots was reduced by those which should have been sold in the previous year. Based on the above assumptions, it could be assumed that approx. $32 \%$ plots out of the general number of 1,324 plots subject to the planning fee will never be sold within the period established for the purpose of this analysis. According to Słojewski 
and Witkiewicz (2005), the highest probability of selling property designated for investment purposes is in the second year after passing the local spatial development plan. In the $5^{\text {th }}$ year after passing the plan, the probability falls to the lowest level. Based on the above, the highest possible income for the commune can be achieved within the first two years after the local plan is passed.

Taking into account general income into the commune budget, which for example in 2014 was approx. 21.3 million PLN, and the projected income from planning fees of $10 \%$ of the difference in plot value, it is possible to calculate the hypothetical income to the commune budget in the subsequent 5 years. Based on this calculation, in the first year, the expected income could be approx. $11 \%$ of average yearly income of Tomice Commune. In the second year, this value may rise to $13 \%$. Consequently, in years 3,4 , and 5 - only slightly above $3 \%, 2.8 \%$, and $1.3 \%$ can be expected to be achieved, which throughout the period of 5 years, gives a sum of approx. $30 \%$ of the projected income per one calendar year.

\section{Conclusions}

The provisions of the local spatial development plan shape, along with other regulations, the means of exercising the right of ownership. Everyone has the right (within the limits set by law) to manage the land to which they have a legal title, under the conditions set out in the local spatial development plan or decisions regarding land development, as long as the actions of the owner do not violate the public interest and third parties. The sale and purchase of land are actions that bring measurable benefits of the ownership right. The benefits are higher if the land is designated for investment purposes, because re-zoning decisions produce direct economic effects in the form of changes in property value covered by the findings of the local plan. Provisions of the currently binding Act on Spatial Planning and Management introduced the obligation of determining percentage rates, i.e. so-called planning fees, collected within 5 years from the date of adopting the local plan. These fees are the results of an increase in the value of property, which can be traded on the real estate market. Also introduced was the obligation to draw up forecasts of the financial consequences of passing local spatial plans, whose main element is an estimate of the possible profits or losses resulting from planning decisions changing land designation patterns.

The presented simplified estimate of profits that could be achieved by Tomice Commune from planning fees provides relevant information for the analyzed commune, referring to the most important financial document - the budget. Since the forecast is based on the study of conditions and directions of spatial development, it can be concluded that the article is a cost and feasibility analysis of the planning decisions that took place in 2004. Moreover, based on the analysis of planning documents issued in 2004, it can be noted that the commune has undergone intensive changes which have reshaped it into a suburban area; this can be concluded by noting the increased amount of land designated for investment purposes. At the same time, the commune has registered an intensive growth of population, which was due to a positive migration ratio and birth rate. The changes were also triggered by the close locations of large urban areas: Wadowice and Krakow. With the passing of the new local spatial development plan in the future, it may turn out that more agricultural land will be designated for residential purposes, thus its value will increase. This is an opportunity to set up a planning fee that will partly compensate the costs of drawing up the local plan and will be a direct source of income for the commune budget.

It may be also concluded that the forecast of the financial consequences of the adoption of a local plan is not a legal act, yet it has a significant impact on the content of the local law in the local spatial development plan, including the execution of constitutional property rights.

\section{References}

BAJEROWSKI T. (red.), 2008, Zarzadzanie przestrzenne. Teoretyczne i praktyczne aspekty prognozowania finansowych skutków opracowań planistycznych (Spatial management. Theoretical and practical aspects of financial forecasting of the effects of planning studies), Wyd. UWM Olsztyn..

BAŃSKI J., WESOŁOWSKA M., 2010, Transformations in housing construction in rural areas of Poland's Lublin Region - influence on the spatial settlement structure and landscape aesthetics, Landscape and Urban Planning 94, pp. 116-126. 
BIEDA A., HANUS P., HYCNER R., 2012, Geodezyjne aspekty planowania przestrzennego $i$ wybranych opracowań projektowych (Surveying Aspects of Spatial Planning and Selected Project Designs), Wyd. Gall, Katowice.

BĄKOWSKI T., 2004, Ustawa o planowaniu i zagospodarowaniu przestrzennym. Komentarz (Act on Spatial Planning and Management. Commentary), Kraków.

BÜrgi M., Hersperger A. M. \& SCHNEEBERGER N., 2005, Driving Forces of Landscape Change - Current and New Directions, Landscape Ecology, 19(8), pp. 857-868.

BydŁosz J., Hanus P., 2013, The Impact of Landslide Areas on Municipal Spatial Planning, Real Estate Management and Valuation, Vol. 21, No. 4, pp. 5-10.

CYMERMAN R. (red.), 2011, Podstawy planowania przestrzennego i projektowania urbanistycznego (Fundamentals of Spatial Planning and Urban Design), Wyd. UWM Olsztyn.

CYMERMAN R., BAJEROWSKI T, KRYSZK H., 2006, Prognoza skutków finansowych uchwalenia miejscowego planu zagospodarowania przestrzenneg (Forecats of Financial Effects of the Adoption of Local Spatial Development Plan), Wyd. Educaterra, Olsztyn.

CYMERMAN R., GRABOWSKI Z., 1999, Renta planistyczna jako czynnik rozwoju przestrzennego (Planning Fee as Factor of Spatial Development), ZN AR w Krakowie, nr 353, s. 90.

CZEKIEL-ŚWITALSKA E., 2002, Miejscowy plan zagospodarowania przestrzennego a skutki ekonomiczne jego uchwalenia (Local Spatial Plan vs, Economic Effects of its Adoption). Przestrzeń i forma 2002, nr 1, s. 8792.

DUDZIŃSKA M., KOCUR-BERA K., 2014, Information on the Environment and its Protection in Real Property Management, Real Estate Management and Valuation, Vol. 22, No. 3, pp. 93-103.

FOGEL P., 2010, Obszary problemowe rolnictwa w świetle planowania miejscowego (Challenges in Agriculture in the Context of Local Planning), Studia i Raporty IUNG PIB, Zeszyt 19, s.19-26.

GAWROŃSKI K., 2008, Wybrane aspekty prawa własności w planowaniu przestrzennym (Selected Aspects of the Property Right in Spatial Planning), Zeszyty Naukowe Wyższej Szkoły Bankowości i Finansów w Bielsku-Białej, Prace z Zakresu Ekonomi, Nr 1, Wydawnictwo WSBiF Bielsko-Biała, s. 25-37.

HAUSER R, I IN., 1995, Ustawa o zagospodarowaniu przestrzennym z komentarzem i przepisami wykonawczymi (Act on Spatial Planning with Commentary and Executive Regulations), Wydawnictwo Prawnicze, Warszawa 1995.

Hernik J., GAWrońsKi K., DixOn-GOUGH R., 2013, Social and Economic Conflicts Between Cultural Landscapes and Rural Communities in the English and Polish Systems, Land Use Policy 30 (2013) pp. 800-813.

http://www.tomice.pl.

KOnStytucja RZeczypospolitej POlskiej, Ustawa z dnia 2 kwietnia 1997 r. (CONSTITUTION OF THE RePublic Of POlAnd, Act of 2 April 1997) Dz.U. nr 78 poz. 483 z 1997 r. z późniejszymi zmianami (Journal of Laws, No. 78, item 483 as amended).

KWAŚNIAK P., 2009, Plan miejscowy w systemie zagospodarowania przestrzennego (Local Plan in the System of Spatial Planning), Wyd. LexisNexis, Warszawa.

MROZIK K., BOSSY M., ZARĘBA K., 2012, Polityka przestrzenna gmin wiejskich na tle zmian zagospodarowania przestrzennego wynikajacych $z$ suburbanizacji (Spatial Policies in Rural Comunes in the Context of Economic Changes Brought on by Suburbanization), Rocznik Ochrona Środowiska Vol. 14, pp. 761-771.

MROZIK K., WIŚNIEWSKA A., 2013, Miejscowe plany zagospodarowania przestrzennego jako instrument zarzadzania procesem suburbanizacji na terenach wiejskich a przykładzie obrębu geodezyjnego Skórzewo (Local Spatial Management Plans as an Intrument for Managing Suburbanization Processes in Rural Areas Exemplified by the Cadastral Unit of Skórzewo), Rocznik Ochrona Środowiska, Vol. 15, pp. 2126-2141.

NiEWIAdOMSKI Z., 2003, Nowe prawo o planowaniu i zagospodarowaniu przestrzennym (New Law on Spatial Planning and Management), Warszawa.

POMPKA D., 2013, Empiryczne oszacowanie wartości nieruchomości w gminie Tomice (Empirical Assessment of the Value of Real Estate in the Commune of Tomice), Maszynopis. Praca magisterska przygotowana w Katedrze Gospodarki Przestrzennej i Architektury Krajobrazu.

PRUS B., 2012, Kierunki zmian przeznaczenia gruntów rolnych i leśnych w Polsce (Directions of Agricultural and Forest Land Changes in Poland), Acta Scientiarum Polonorum. Geod. Descr. Terr. 11(2), pp. 27-40.

Rozporządzenie Ministra Infrastruktury z dnia 26 sierpnia 2003 r. w sprawie wymaganego zakresu projektu miejscowego planu zagospodarowania przestrzennego (Regulation of the Ministry of Infrastructure of 26 August 2003 on the Required Scope of a Spatial Plan Project). Dz. U. nr 164, poz. 1587 z 2003 r. (Journal of Laws of 2003, No. 164, item 1587). 
SKRZYDŁO W. 2002. Konstytucja Rzeczypospolitej Polskiej. Komentarz (Constitution of the Republic of Poland. Commentary), Kraków. s.32.

SŁOJEWSKI R., WITKIEWICZ Z., 2005, Prognoza skutków finansowych uchwalenia miejscowego planu zagospodarowania przestrzennego (Forecast of Financial Effects on Passing Local Spatial Development Plan), IDM. Warszawa.

SPRINGER F., 2013, Wanna z kolumnada (Bath with colonnade), Wyd. Czarna. Warszawa.

SZWAJDLER W., BĄKOWSKI T., 2004, Proces inwestycyjno-budowlany. Zagadnienia administracyjno-prawne. (Investment and Land Development Process. Administrative and Legal Aspects), Torun.

ŚWIETLIK M., 2003, Planowanie przestrzenne w gminie (Spatial planning in a commune). (w:) BUCZEK G., Ustawa o planowaniu i zagospodarowaniu przestrzennym, przepisy - omówienia - komentarze ([in:] Buczek G. Act on spatial planning and management, regulations - interpretations commentaries).

ŚWIETLIK M., 2004, Prognoza skutków finansowych uchwalenia miejscowego planu zagospodarowania przestrzennego (Forecast of Financial Effects of Passing a Local Spatial Development Plan), Biblioteka Urbanisty, Warszawa.

UNIWERSAŁ P., 2014, Wyznaczenie hipotetycznych obszarów oddziaływania opłaty adiacenckiej $i$ renty planistycznej w gminie Tomice (Determining of Hypothetical Areas of Adjacency Fee and Planning Fee in the Commune of Tomice), Maszynopis. Praca magisterska przygotowana w Katedrze Gospodarki Przestrzennej i Architektury Krajobrazu.

Ustawa z dnia 27.03.2003 r. o planowaniu i zagospodarowaniu przestrzennym (Act of 27 March 2003 on Spatial Planning and Management). Dz. U. nr 80, poz. 717 z późn. zm. (Journal of Laws, No. 80, item 717 as amended). 